\title{
Technical Aspects of Official Letters from Caliph Umar Ibn Al-Khattab
}

\author{
Naeem Ashfaq, Hussin Bin Salamon, Mohd Fauzi bin Abu Hussin, Nasrul Hisyam bin Nor \\ Muhamad, Sulaiman Shakib Bin Mohd, Aminuddin Bin Ruskam
}

\begin{abstract}
The period of 'Umar ibn al-Khattab's caliphate is undoubtedly the golden age of Islam in every respect. Having prophet Muhammad as a the messenger of Islam, he is the architect of the Islamic State in its technical sense. Within the period of his glorious administration, he was not only able to extend the wings of Islam east and west, thus making the Islamic state was the biggest single states at that time. This study aims to explore the official letters addressed to different officials of the Islamic State by Caliph 'Umar ibn al-Khattab. These letters reflect his ultimate capabilities in managerial skills on ethnic and linguistic tendencies through the linking forces of Islam. The method is library-based research, and the collected data is taken from secondary sources, which was collected from different classical books. The outcomes of this study show that these letters have multi-faced guidelines, which may be adopted and implemented from high to low levels of management in organizations. Additionally, this research depicts that how different type of groups and officials should be communicated, instructed and managed through effective communication means in a various academic and real environment.
\end{abstract}

Index Terms: Caliph 'Umar ibn Al-Khattab, Official Letters, Categorization, Managerial Qualities, Divine Guidance

\section{INTRODUCTION}

The period of Caliph 'Umar's caliphate undoubtedly is the "Golden Age" of Islam in every respect. He was a man of extraordinary genius who not only molded the destiny of the nation but made the history of his own. He fully followed the footsteps of the Holy Prophet. He was an exemplary administrator who originated an efficient system of administration. He implemented Shari'ah (Divine Islamic Law) as the code of a newly formed International Islamic State. He safeguarded the internal safety by introducing the police force. He gave stipends to the poor and founded new cities for the growth of Islamic culture and civilization. He improved agriculture \& economics and founded the educational system. Shortly, he was the founder of a great modern state (Alam, 2017).

Whenever is mentioned the genius lawmakers or military commanders or senior administrators, the researchers will find caliph 'Umar is a leader of every group and great of every sect. If someone searches the great men who built nations, and those who left an impact in the world, no one will not find great of them than Umar. Weihrich and Koontz (1995) stated he did not go to any management school for training, but his education, wisdom, and especially his

\footnotetext{
Revised Manuscript Received on April 19, 2019.

Naeem Ashfaq,

Hussin Bin Salamon,

Mohd Fauzi bin Abu Hussin,

Nasrul Hisyam bin Nor Muhamad,

Sulaiman Shakib Bin Mohd,

Aminuddin Bin Ruskam
}

company of the prophet allowed him to master the art of management. The general features of Umar's leadership are his sense of responsibility, following participated management style, application of total quality management, his full understanding of control process and major administrative innovations during his rules. Caliph Umar managed to deal with all matters in a great way, and it's Phenomenal that he was only initiator and creator of these administrations without following a precedent as the prophet said that I did not see any genius, who did at its best like Umar (Al-Nawawy, 1996).

Umar bin Al Khattab's letters addressed to different officials reflect the working of managing the affairs of different groupings based on ethnic, linguistic tendencies through the linking forces of Islam. This policy is in continuation of the strategy applied by his predecessors Caliph Abu Bakr and the Messenger of Allah (Peysepar \& Attashi, 2016). As can be seen through the pages of history, in a few years after Hijrah, the Prophet of Allah carried the message of Islam in the far-off distant corners of Arabian Peninsula and thus laid the foundations of Islamic State as enunciated in the Quran, "(O Prophet,) When there comes Allah's help and the Victory, and you see people entering Allah's (approved) religion in multitudes (Al-Nasr: 1-2).

There was a constant flow of incoming and out-going emissaries seeking instructions, orders and commandments regarding impending victories, diplomatic maneuvering, the establishment of law and order situation, different covenants, the supply of arms and ammunition, disposal of booty, Jizyah and Zakah matters including other civil and military affairs. All these state matters, more or less needed urgent, instantaneous attention of the Khalifah in Islam (Hamidullah, 1987).

In contradiction to the above-cited position, there was no regular office of the Khalifah, and there was a skeleton staff to look after. His mode was to write a few words on the back of the letters and applications received from concerned officials and elaborated them before those who brought them inculcating the exact meaning and purport of the message from the central authority. In the absence of any written, message from the official concerned, the instructions or orders were communicated to them on a small piece of paper or a leather piece (F'ariq, 1978a).

These letters cover various fields of the administration, in different subjects, matter, variety of volume with different shades of meanings. This may be due to the reporting of the persons and the subsequent narration of the Aasaar - reports 
by the persons coming after them. The writings of the second Khalifah of Islam, 'Umar indicates his tight, rough and tough nature as a strict disciplinarian and acute diplomat, imbibed with the spirit of truth, enforcing Shariah. 'Umar represents unanimously the one central theme - the art of managing the affairs of different ethnic groupings, based on linguistic varieties, races, castes, colors and creeds. This process continued in one form or the other whether in crude form or uniform through the Khalifah in Islam - the central authority to supervise the affairs of Muslim Ummah according to the Quran and the practice and precept of the Sunnah of the Holy Prophet Muhammad. Its revival is of far vital importance for the consolidation of Muslim Ummah and its regeneration among the polity of the different nations of the world.

In fact by applying our sense of pick and choose the above-cited small, pithy letters have been selected that seem to be the probable writing of the second Caliph in Islam, 'Umar Ibn Al-Khattab and seem to have been written by the scribe in his command by going through the huge historical record available in the form of letters pertaining to the period of the second Caliph in Islam, 'Umar ibn Al-Khattab.

The major contribution to this research study as follows:

1) Data collection in the form of letters.

2) Categorization of these letters regarding managerial aspect.

3) Impact of themes on management, specifically topdown approach.

4) Attributes of letters regarding managerial qualities

Letters of Caliph 'Umar has been stated and quoted in several books. Some work of scholars has done to compile these letters in one place, and a little work is done on specific letters of the caliph 'Umar regarding mass communication. However, no one has done work on the categorization of these letters regarding managerial aspect. So, there is a need to categorize these letters in such a way that they have a strong impact and beneficial for organizations at every level of management.

\section{LITERATURE REVIEW}

The letters of Umar have been stated in different classical books, and some mentioned in his biographies in political, managerial and social context such as Nu'mani (1939) mentioned some letters under some topics which are stated the generic quality of Caliph 'Umar and As-Șallābī (2007) also done such type of work. He focused on the entire life of 'Umar and under this theme and also, cited some letters. Irving (1849) also have done on Prophet Muhammad, and under this theme, he stated the biographies of Prophet's successors and mentioned their letters. While T'aj (2007) has specifically studied the letters of Khulafah e Rashideen in which she examined 18 letters of Caliph 'Umar in the context of Mass communication and investigated journalistic and mass communicative functions and characteristics of these entities.

Umar represents unanimously the one central theme - the art of managing the affairs of different ethnic groupings, based on linguistic varieties, races, castes, colors and creeds. This process continued in one form or the other whether in crude form or uniform through the Khalifah in Islam - the central authority to supervise the affairs of Muslim Ummah according to the Quran and the practice and precept of the Sunnah of the Holy Prophet Muhammad. Its revival is of far vital importance for the consolidation of Muslim Ummah and its regeneration among the polity of the different nations of the world.

\section{METHODOLOGY}

From the linguistic diachronic point of view; letter writing is a particularly rewarding object of study since epistolary discourse is perhaps the most ancient form of attested writing (Petrucci, 2008). Socio-linguists, social historians, and literary scholars have become increasingly interested in the letter as genre and letter writing as social and cultural practice (Camiciotti, 2014). As indicated by Nevalainen and Tanskanen (2007), letter writing has always been a situated activity, so its material circumstances and discursive practices have naturally changed over time and may vary according to the context of use.

The right letter can make all the difference. From getting the right job to closing the sale, from obtaining a scholarship to offering thanks gracefully, letters leave a lasting impression. Containing more than just cover letters and thank-you notes, this title also covers such common correspondence as wishing congratulations, apologizing, expressing sympathy, fundraising, asking favors, requesting and providing information, job hunting, selling, making and responding to complaints, giving feedback, refusals, or reprimands, and even collecting past-due payments (Bly, 2004).

The letters of Caliph 'Umar written to different persons and areas were in many classical historical books. Dr. Khursheed Ahmad F'ariq collected 454 letters and translated in Urdu language. These letters were published in India in 1959. He collected all letters which are stated by different scholars and historians in their books (F'ariq, 1978). From these letters, many letters of the same topic have mentioned in different books. He collected all of them, but his work is focused only on the collection of letters. Dr. Hameed Allah collected letters and covenants of Prophet Muhammad and Khulafah e Rashideen. In his book, under the title of Caliph 'Umar, he stated different letters of different subjects (Hamidullah, 1987). Adil (1991) compiled 192 Letters of Caliph 'Umar and translated in English. These letters are written to different people such as governors, military commanders, masses etc. and stated in 40 different books (see the table in appendix A). For this study, these letters the work of Dr. Muhammad 'Adil was selected for categorization.

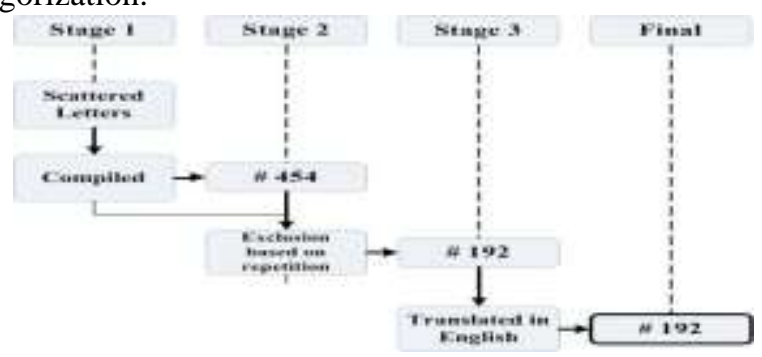

Figure 1: Illustration of the study selection process

Blue Eyes Intelligence Engineering

\& Sciences Publication 
In this research, the letters of Caliph 'Umar, which was written to different officials, are categorized into different categories. This study also shows how he instructs different people in respective conditions, which reflects the managerial and leadership qualities and skills of Caliph 'Umar as well as his approaches to manage and lead the masses. For this purpose, 17 categories emerge from 192 letters. For each category, related letters are mentioned with their themes, and these themes indicate the managerial and leadership qualities of Caliph 'Umar.

\section{A. Governors}

The first category emerged from those letters which were written to governors of different Islamic states such as Syria, Persian and Egypt. Under this category, there are 31 letters. Caliph 'Umar instructed upon their request and information provided to Caliph 'Umar. Following managerial qualities emerged from his instruction given in the letters, which shows his art of administration. Table 1 shows the details in brief.

As a leader, he trusted and participated in Participatory management $(\mathrm{PM})$ his subordinates to take decisions themselves according to the situation and encourage them on their actions and achievements and praise to motivate them. Along with their accountability and getting corrective measures (CM) for their wrongdoings. While decision making (DM), he considers the sayings of Prophet Muhammad also.

Results show that he has a keen interest in the welfare of Masses, shows kindness towards them and instructed their governors to do so by remembering the concept of Ummah. Caliph 'Umar as an administrator also shows his attention for Human Resource Management (HRM) for an appointment he chose the best person for the job and preferred the Muslims and look for a pious as well as a skilled person. Regarding financial management (FM), he plans according to Shariah law.

\begin{tabular}{|c|c|c|}
\hline \multicolumn{3}{|c|}{ Abu Ubaidah bin Jarrah; Syria } \\
\hline Letter & Details & Theme \\
\hline 1 & Trust and involve subordinates to make decisions, some & $\begin{array}{l}\mathrm{DM} \\
\mathrm{PM}\end{array}$ \\
\hline 2 & Accountability of Khalid for the wasteful act & Accountability \\
\hline 3 & $\begin{array}{l}\text { Accountability of those wrongdoers who argue from Quran, } \\
\text { Implement Hadd. }\end{array}$ & $\begin{array}{l}\text { Accountability } \\
\text { CM }\end{array}$ \\
\hline 4 & $\begin{array}{l}\text { Motivate or encourage those who committed drinking wine \& } \\
\text { punished by reciting Qur'an }\end{array}$ & $\begin{array}{l}\text { Motivation } \\
\text { CM }\end{array}$ \\
\hline 5 & $\begin{array}{l}\text { Accountability and Corrective measures, who cited Qur'an wrongly } \\
\& \text { awarded punishment. }\end{array}$ & $\begin{array}{l}\text { Accountability } \\
\text { CM }\end{array}$ \\
\hline 6 & $\begin{array}{l}\text { Corrective measures for Abu Jundal, Link to Allah (repentance, } \\
\text { strict punishment, forgiver), Referring Quran }\end{array}$ & $\begin{array}{l}\text { Accountability } \\
\text { CM }\end{array}$ \\
\hline \multicolumn{3}{|c|}{ Yazid bin Abi Sufyan; Syria } \\
\hline Letter & Details & Theme \\
\hline 1 & Decisions based on the sayings of the Messenger of Allah. & DM \\
\hline 2 & $\begin{array}{l}\text { Analyze the situation for decision making Victory of Qaisairiyah in } \\
\text { Syria is due to Allah. }\end{array}$ & DM \\
\hline \multicolumn{3}{|c|}{ Ayaz bin Ghanam; Syria } \\
\hline 1 & $\begin{array}{l}\text { Appointment letter, Instructions to do the job with responsibility } \\
\text { and nicely. }\end{array}$ & $\begin{array}{c}\text { HRM } \\
\text { Responsibility } \\
\end{array}$ \\
\hline 2 & $\begin{array}{l}\text { Praise, encourage \& Motivate subordinate, discuss the situation, } \\
\text { Referring Quran and Prophet, Instructions to consult with Yazid } \\
\text { (expert opinion). }\end{array}$ & $\begin{array}{l}\text { Motivation } \\
\text { DM } \\
\text { PM }\end{array}$ \\
\hline 3 & Reminder about revenues for wages, Importance of finances. & FM \\
\hline 4 & $\begin{array}{l}\text { The abundance of wealth, is bad, } \\
\text { Do best for the cause of Islam \& Muslims, Instructions to reach as } \\
\text { early as possible to Syria \& get position due to the illness of Abu } \\
\text { Sufyan, Muslim solidarity is important. }\end{array}$ & Care of subordinates \\
\hline \multicolumn{3}{|c|}{ M'uawiyah bin Abi Sufyaan; Syria } \\
\hline 1 & $\begin{array}{l}\text { Instructions about masses. } \\
\text { Kindness with the public, Special care of stranger for his welfare } \& \\
\text { give him justice. }\end{array}$ & Care of subordinates \\
\hline 2 & $\begin{array}{l}\text { Advice to be truthful in every matter while decision making, } \\
\text { Allah will show you the right path. }\end{array}$ & DM \\
\hline
\end{tabular}




\begin{tabular}{|c|c|c|}
\hline \multicolumn{3}{|c|}{ Abu Musa As'hiri; Persian (Ahwaz, Tustar, Manazir etc.) } \\
\hline 1 & $\begin{array}{l}\text { Instruct to send help to AHWAZ. } \\
\text { Appointments of officers. }\end{array}$ & $\begin{array}{l}\text { Teamwork } \\
\text { HRM }\end{array}$ \\
\hline 2 & $\begin{array}{l}\text { Detailed instructions for the task. Situational analysis, treat } \\
\text { subordinates with kindness, do not commit sins, do Justice, Victory } \\
\text { with true believers, Motivation. }\end{array}$ & $\begin{array}{c}\text { DM } \\
\text { Care of subordinates } \\
\text { Concept of success } \\
\text { Development } \\
\text { Motivation }\end{array}$ \\
\hline 3 & Instructions to give one share of the booty for Turkish horses. & FM \\
\hline 4 & $\begin{array}{l}\text { Accept \& Sign the } 7 \text { points of the covenant with the chief of } \\
\text { Aswaris. }\end{array}$ & $\begin{array}{l}\text { DM } \\
\text { FM }\end{array}$ \\
\hline 5 & $\begin{array}{l}\text { Instructions to bury Prophet Daniyal with respect (from Babul to } \\
\text { Soos) \& deposit money in the state treasury. }\end{array}$ & FM \\
\hline 6 & $\begin{array}{l}\text { Instructions to give a share of the heritage of Haska to his father \& } \\
\text { grandmother. }\end{array}$ & FM \\
\hline 7 & $\begin{array}{l}\text { Heritage of a dead person who has no heirs should be deposited as } \\
\text { state property. }\end{array}$ & FM \\
\hline 8 & $\begin{array}{l}\text { Heritage for grandfather in the absence of father witnessed by Abu } \\
\text { Bakr. }\end{array}$ & FM \\
\hline 9 & $\begin{array}{l}\text { Strictly avoid making conjugal relations with slaved pregnant } \\
\text { women because of polytheists. }\end{array}$ & $\mathrm{CM}$ \\
\hline 10 & $\begin{array}{l}\text { Instructions about cultivation, Free that slaves for cultivation, } \\
\text { Realize land revenue from them. }\end{array}$ & FM \\
\hline 11 & $\begin{array}{l}\text { Same orders as above for Manazirs due to identical with people of } \\
\text { Ahwaz. }\end{array}$ & FM \\
\hline 12 & $\begin{array}{l}\text { Action against the appointment of mathematician, justify by giving } \\
\text { a reason that Allah has taken post \& rank away from non-believers. } \\
\text { Encourage to learn mathematics. }\end{array}$ & $\begin{array}{l}\text { HRM } \\
\text { Criteria for appointment } \\
\text { Motivation }\end{array}$ \\
\hline 13 & $\begin{array}{l}10 \% \text { Tax on belligerent Merchandize, } 5 \% \text { on Dhimmis. } \\
2.5 \% \text { on Muslims on commercial merchandize in the valuation of } \\
200 \text { Dirhams, one dirham on every } 40 \text { dirhams merchandize. }\end{array}$ & FM \\
\hline \multicolumn{3}{|c|}{ Amr bin Aas; Egypt } \\
\hline 14 & Leaders a are the servant of Allah, Aid for famine in Madinah. & $\begin{array}{l}\text { Leadership, FM } \\
\text { Teamwork }\end{array}$ \\
\hline 15 & $\begin{array}{l}\text { Fast transportation means for Drought, Order to digging a canal } \\
\text { from the Nile to sea even spent entire treasury of Egypt. }\end{array}$ & $\begin{array}{c}\text { FM } \\
\text { Teamwork } \\
\text { Execution of task }\end{array}$ \\
\hline 16 & $\begin{array}{l}\text { Accountability for excess in wealth \& property, Send Muhammad } \\
\text { bin Maslamah to get half of his Assets. }\end{array}$ & $\begin{array}{c}\text { FM } \\
\text { Accountability }\end{array}$ \\
\hline \multicolumn{2}{|c|}{ Total Letters } & 31 \\
\hline
\end{tabular}

\section{B. Provincial Governors}

Caliph 'Umar wrote letters, not only to top management such as governors, but he also connected with middle management directly. He sent 25 letters to the provincial governors in the areas of Syria, Yemen, Ta'if, Basra, Kufa, Ahw'az, and Bahrain., The gist of emerging themes, is managerial features are presented in Table 2.

In these letters, Caliph 'Umar showed his keen interest to link his middle management with Allah while doing the jobs. He instructed them to care the subordinates, give priority for the welfare of the public, respect the seniors, and obedient to law and seniors. He was also concerned for caring the government instruments. He encouraged and motivated them by giving tangible help. He believed in teamwork and advice his subordinates to do as same.
He appointed a more skilled person on the job. While decision making (DM), he made the first situational analysis and then decided according to the Quran and Sunnah of the Prophet Muhammad. He does every job with a sense of responsibility and accountability. Controlling is the main feature of Caliph 'Umar's management. He takes corrective measures $(\mathrm{CM})$ due to the wrong act of his subordinates Financial management (FM) of Caliph is based on Islamic law. He made strategies after realizing risks (Risk Management RM). 


\begin{tabular}{|c|c|c|}
\hline Letter & Details & Theme \\
\hline \multicolumn{3}{|c|}{ All provincial governors; Syria } \\
\hline 1 & $\begin{array}{l}\text { Check grape drink prepared on fire (gifted by a Monk). } \\
\text { Instruct to give grape drink to subordinates as a government ration. }\end{array}$ & Care of subordinates \\
\hline \multicolumn{3}{|c|}{ Ya'la bin Umayyah; Yemen } \\
\hline $\mathbf{1}$ & Impose one fifth as Tax on "Amber”, God gifted. & FM \\
\hline 2 & $\begin{array}{l}\text { Instructions about conquered land, Levy on uncultivated lands and } \\
\text { production of the gardens. } \\
\text { Shares for cultivators and state Treasury. }\end{array}$ & FM \\
\hline 3 & Strict instructions about Qis'as of a child, Execution of Hadd. & DM according to shariah law \\
\hline 4 & Tax on Amber, Sea items should be levied one fifth as tax. & FM \\
\hline \multicolumn{3}{|c|}{ Sufyan bin Abdullah Saqafi; Ta'if } \\
\hline 5 & Guide upon shariah law, regarding sucking milk. & Shariah law \\
\hline \multicolumn{3}{|c|}{ Utbah bin Ghazwan; Basra } \\
\hline 1 & $\begin{array}{l}\text { To protect 'Ala bin Hadhrami, adopted sea route to attack Persians, } \\
\text { He took a step to attack without permission, } \\
\text { Take care \& help subordinate. } \\
\text { The situation is a danger for him }\end{array}$ & $\begin{array}{l}\text { Care of subordinates } \\
\text { Detailed strategy } \\
\text { RM }\end{array}$ \\
\hline \multicolumn{3}{|c|}{ Mughirah bin Shu'ba; Basra } \\
\hline 1 & $\begin{array}{l}\text { Appointment after Utbah's death. Instructions to allot land to Naafi' } \\
\text { for breeding the horses, Appreciate Naafi' act, Dhimmi's land should } \\
\text { not be given to him }\end{array}$ & $\begin{array}{l}\text { HRM } \\
\text { Motivation } \\
\text { FM }\end{array}$ \\
\hline 2 & $\begin{array}{l}\text { Dismiss due to the serious allegation, Strict accountability. } \\
\text { Order come back to Madinah. }\end{array}$ & $\begin{array}{l}\text { Accountability } \\
\text { Dismissal } \\
\end{array}$ \\
\hline \multicolumn{3}{|c|}{ Ammar ibn Yasir \& people of Kufa; Kufa } \\
\hline 1 & $\begin{array}{l}\text { Appointment of Ammar as a governor, Abdullah ibn Mas'ud as } \\
\text { Qur'an instructor \& minister advisor, Justification for chosen is } \\
\text { Sahabi e Rasul }\end{array}$ & $\begin{array}{c}\text { HRM } \\
\text { Justification }\end{array}$ \\
\hline 2 & $\begin{array}{l}\text { Qisas or Diyyah of Dhimmi. } \\
\text { Justice. }\end{array}$ & Application of shariah law \\
\hline 3 & Rejected USR from women from Baghdad instead of Jizya. & FM \\
\hline \multicolumn{3}{|c|}{ S'ad bin Abi Waqqas; Kufa } \\
\hline 1 & $\begin{array}{l}\text { Instructions to send help to AHWAZ, Appointments of suitable } \\
\text { officers, Investigation of plan of the enemy, Strategy to march } \\
\text { towards headquarter of Hurmuzan (Persian commander). }\end{array}$ & $\begin{array}{c}\text { Teamwork } \\
\text { HRM } \\
\text { Planning } \\
\text { RM }\end{array}$ \\
\hline 2 & $\begin{array}{l}\text { Instructions about the care of horses, prohibit emasculation of horses, } \\
\text { Give them rest. Not run them } \mathbf{2} \text { miles in one stretch. }\end{array}$ & Care of instruments \\
\hline 3 & Do not cut the hand of a thief (Bait ul Maal). & $\begin{array}{c}\text { DM } \\
\text { Shariah law }\end{array}$ \\
\hline 4 & Rejected USR from women from Baghdad instead of Jizya. & FM \\
\hline 5 & $\begin{array}{l}\text { Excess money of booty should be distributed among reciters of } \\
\text { Qur'an \& who have meritorious services in war. }\end{array}$ & FM \\
\hline 6 & $\begin{array}{l}\text { Appreciate subordinate's meritorious services. Order to give more to } \\
\text { him. }\end{array}$ & $\begin{array}{c}\text { FM } \\
\text { Motivation }\end{array}$ \\
\hline 7 & $\begin{array}{l}\text { Revise his orders to pay Quran reciters to discourage them because } \\
\text { they started reciting for money, give excess money to best warriors. }\end{array}$ & $\begin{array}{l}\mathrm{CM} \\
\mathrm{FM}\end{array}$ \\
\hline 8 & $\begin{array}{l}\text { Advice \& realize responsibility. } \\
\text { The welfare of people, Divine rewards for whom from those people } \\
\text { benefited. }\end{array}$ & $\begin{array}{l}\text { Responsibility } \\
\text { Welfare of people }\end{array}$ \\
\hline 9 & $\begin{array}{l}\text { Realize the critical situation of NIHAWAND. Instruct to send the } \\
\text { best person, Right person for the right job. }\end{array}$ & $\begin{array}{c}\text { HRM } \\
\text { Situational analysis }\end{array}$ \\
\hline
\end{tabular}




\begin{tabular}{|c|c|c|}
\hline 1 & $\begin{array}{l}\text { Instructions to send help for Nauman, Detailed strategy for the } \\
\text { move, Parallel plan. }\end{array}$ & $\begin{array}{l}\text { Teamwork } \\
\text { RM } \\
\text { Planning }\end{array}$ \\
\hline 2 & $\begin{array}{l}\text { Analyze the critical situation. } \\
\text { Appreciate Ahnaf bin Qais. } \\
\text { Give instructions. Motivate for Jihad. Be informed about the } \\
\text { current situation. }\end{array}$ & $\begin{array}{l}\text { HRM } \\
\text { Encourage } \\
\text { Decision making } \\
\text { Motivation }\end{array}$ \\
\hline \multicolumn{3}{|c|}{ Ala bin Hadrami; Bahrain } \\
\hline 1 & $\begin{array}{l}\text { Appointed governor of Basra. } \\
\text { Remind the status of the Appreciate Muhajireen. } \\
\text { Removed Utbah due to lack of skills. } \\
\text { This world is a passing phase, and the Hereafter is eternal and } \\
\text { abiding. }\end{array}$ & $\begin{array}{l}\text { HRM } \\
\text { Concept of Akhirah } \\
\text { Respect the seniors } \\
\text { Appoint more skilled person on } \\
\text { the job }\end{array}$ \\
\hline 2 & $\begin{array}{l}\text { Almighty Allah endowed authority on obedience. In the absence of } \\
\text { obedience, there is disorder, lawlessness and confusion in society. } \\
\text { Prepared an army endangering the lives of the Muslims without my } \\
\text { permission. } \\
\text { Send an army for the help of Sa'd bin Abi Waqqas and save you } \\
\text { from destruction. }\end{array}$ & $\begin{array}{l}\text { Obedience } \\
\text { Accountability } \\
\text { Teamwork } \\
\text { Encourage by giving tangible } \\
\text { help } \\
\text { Take care of subordinates }\end{array}$ \\
\hline \multicolumn{2}{|c|}{ Total letters } & 25 \\
\hline
\end{tabular}

\section{Commanders in chiefs}

Caliph 'Umar sent 79 letters to the commander in chiefs of two main fronts at that time, for instance, Syria and Forces in Iraq. Main themes emerge from these letters are stated in Table 3, and its descriptive view is as under:

Caliph 'Umar directs under the commands of the Supreme power, Allah, and according to the prophet Muhammad. He instructs to get guidance from the Quran and do himself accordingly.

His training and development style towards the subordinates is unmatchable. His focus is not only on this world, but he uses a comprehensive approach in his development and training of humans. He continuously developed his subordinates by reminding Akhirah, to do for the cause of Islam not for money, to avoid sins and do virtuous deeds.

Regarding leadership qualities, he considers that and custodian of the ummah. He lived a simple life and encouraged subordinates as well. He never cares for any insult while executing the right action or uttering the truth. Keen to fulfil responsibility, steadfast and firm while doing the task. He avoids committing treachery and infidelity. Justice and determination in difficult times are great qualities of 'Umar. His managerial style is participatory and consultation (PM, CM) with his subordinates. $\mathrm{He}$ encourages and motivated his subordinates by saying that no fear and trust of a large number of enemies because he believes numerical and materialistic strength does not matter.

Financial management (FM) is the key part of his administrative qualities. He manages financial matters at the leadership is from Allah the leader is the servant of Allah

micro and macro level wisely and according to Islamic laws. He instructed the officers to evade any situation which could cause harm and danger regarding masses and other things. Regarding Human Resource Management (HRM), he has clear criteria for appointment. He not only observed the skills of the candidate, but he appoints according to need and situation.

Planning and decision making (DM) are the vital quality of a manager. While planning, he maked best plans according to the situationAdditionally, he discussed a detailed strategy to execute the plan and trains his subordinates accordingly. His plans consisted of short-term and long-term approaches along with break down structure (WBS) strategy. Whereas decision making, he acts according to the situation and decides after complete situational analysis. He was extremely judicious during decision making. He believes in teamwork, a strategy based on Ta'awun al Birr grounded in Quran.

As an administrator and a manager, he always put himself the welfare of subordinates, unless Muslims and nonMuslims. He does not put subordinates in danger, do not excess upon non-Muslims, treats the poor with sympathy, encourage them to speak out frankly. He prays for subordinates and wrongdoers. $\mathrm{He}$ does not insult subordinates and reprimands subordinates on their unusual demands. He continuously connects with subordinates and gives compliments to your subordinates and instructs their officers to do the same. 
Accountability is the unique feature of his administrative behavior. His accountability is not only for others, but he always put himself for this. He was continuously taking corrective measures (CM) to control and check the efficiency of subordinates.

\begin{tabular}{|c|c|c|}
\hline Letter & Details & Theme \\
\hline \multicolumn{3}{|c|}{ Abu 'Obaidah bin Jarrah; Syria } \\
\hline $\mathbf{1}$ & $\begin{array}{l}\text { Mentioning Allah, Referring Quran, Leadership Qualities } \\
\text { Avoiding sins, Obedient to Allah, } \\
\text { Do not put Muslims in danger } \\
\text { Beware of opponent }\end{array}$ & $\begin{array}{l}\text { Concept of Success } \\
\text { Leadership Qualities } \\
\text { Care of subordinates } \\
\text { RM }\end{array}$ \\
\hline 2 & $\begin{array}{l}\text { Appointed as Supreme in command of the forces of Khalid bin } \\
\text { Walid. } \\
\text { Look after the Muslims } \\
\text { Perform the duties that are enjoined upon you in that capacity. } \\
\text { Do not send subordinates in perilous places in the hope of booty } \\
\text { by your actions or military expedition. } \\
\text { Almighty Allah has put both of us under test by placing you as my } \\
\text { dependent, and myself as your officer. }\end{array}$ & $\begin{array}{l}\text { Appointment (HRM) } \\
\text { Realize responsibility } \\
\text { Care of subordinates } \\
\text { RM }\end{array}$ \\
\hline 3 & $\begin{array}{l}\text { Inform about the appointment, Dismissal of Khalid, Referring } \\
\text { Quran, Leadership Qualities } \\
\text { Avoiding sins Obedient to Allah } \\
\text { Do not put Muslims in danger } \\
\text { Beware of the enemy, booty }\end{array}$ & $\begin{array}{l}\text { Dismissal (HRM) } \\
\text { Leadership Qualities } \\
\text { RM } \\
\text { FM }\end{array}$ \\
\hline 4 & $\begin{array}{l}\text { Mentioning Allah, Thankful to Allah, Prophethood, Fear of Allah, } \\
\text { Cause of Islam Avoiding sins Concept of Akhirah }\end{array}$ & \\
\hline 5 & Gave a detailed strategy, Victory from Allah, Distribution of task & $\begin{array}{l}\text { Planning } \\
\text { WBS }\end{array}$ \\
\hline 6 & Teamwork & Teamwork \\
\hline 7 & Victory from Allah & \\
\hline 8 & Implement Shariah law, Fear of Allah, Avoiding sins & Accountability \\
\hline 9 & $\begin{array}{l}\text { Mentioning Allah, Encourage subordinates, Victory from Allah } \\
\text { Pray to Allah }\end{array}$ & $\begin{array}{l}\text { Encourage subordinates } \\
\text { Motivation }\end{array}$ \\
\hline $\mathbf{1 0}$ & $\begin{array}{l}\text { Mentioning Allah, Virtuous deeds, Decision making according to } \\
\text { the situation, Future planning to avoid risk, take care of Dhimmis, } \\
\text { do not excess upon non-Muslims }\end{array}$ & $\begin{array}{l}\text { DM } \\
\text { Planning } \\
\text { RM } \\
\text { Care of subordinates }\end{array}$ \\
\hline 11 & Take care of subordinates by avoiding them in danger & Care of subordinates \\
\hline 12 & Corrective measures \& give strategy according to the situation, & $\begin{array}{l}\text { Accountability } \\
\text { Controlling }\end{array}$ \\
\hline 13 & Accountability of elites & Accountability \\
\hline 14 & Encourage, motivate by tangible help & Motivation \\
\hline 15 & $\begin{array}{l}\text { Mentioning Allah, Avoid sins, Dominancy of Allah's } \\
\text { commandments, Referring Quran }\end{array}$ & Controlling \\
\hline 16 & Cause of Islam, Muslim's solidarity \& strength & Care of subordinates \\
\hline 17 & $\begin{array}{l}\text { The manager should be informed all situations, give strategy, take } \\
\text { care of Muslims, motivate by providing tangible help }\end{array}$ & $\begin{array}{l}\text { DM } \\
\text { Planning } \\
\text { Motivation }\end{array}$ \\
\hline 18 & Victory from Allah, Majority of the enemy, does not matter & Concept of success \\
\hline 19 & $\begin{array}{l}\text { Analyze the situation; Supreme power is Allah, motivate } \\
\text { subordinates by referring the Quran, Steadfast in front of the } \\
\text { enemy }\end{array}$ & $\begin{array}{l}\text { DM } \\
\text { Motivation } \\
\text { Steadfast }\end{array}$ \\
\hline 20 & $\begin{array}{l}\text { Analyze the situation, Divine Help, Numerical strength does not } \\
\text { matter, motivate subordinates by referring the Quran }\end{array}$ & $\begin{array}{l}\text { DM } \\
\text { Motivation }\end{array}$ \\
\hline
\end{tabular}


International Conference on Recents Advancements in Engineering and Technology (ICRAET-18) |15th and 16th March 2019|Siddhartha Institute of Technology \& Sciences, Telangana, India.

\begin{tabular}{|c|c|c|}
\hline 21 & Financial management according to the teachings of Prophet & FM \\
\hline 22 & Financial mgt for wages of the Army to pay regularly & $\begin{array}{l}\text { FM } \\
\text { Care of subordinates }\end{array}$ \\
\hline 23 & $\begin{array}{l}\text { Analyze the situation, Divine Help, Motivate subordinates } \\
\text { Participation of subordinates in making decisions }\end{array}$ & $\begin{array}{l}\text { DM } \\
\text { Motivation } \\
\text { PM }\end{array}$ \\
\hline 24 & $\begin{array}{l}\text { Leaders are the servant of Allah } \\
\text { Do the best planning } \\
\text { Steadfast } \\
\text { Welfare of people } \\
\text { Never cares for any insult while executing the right action or } \\
\text { uttering the truth }\end{array}$ & $\begin{array}{l}\text { Leadership qualities } \\
\text { Planning } \\
\text { Good governance } \\
\text { Stand with truth } \\
\text { Welfare of people }\end{array}$ \\
\hline 25 & $\begin{array}{l}\text { Implementation shariah law } \\
\text { Decision making }\end{array}$ & DM \\
\hline 26 & Fin mgt regarding heritance & FM \\
\hline 27 & $\begin{array}{l}\text { Implementation shariah law } \\
\text { Decision making, Obey shariah }\end{array}$ & Decision making \\
\hline 28 & $\begin{array}{l}\text { Obey shariah } \\
\text { Treat the poor with sympathy, encourage him, be extremely } \\
\text { judicious Decision making }\end{array}$ & $\begin{array}{l}\text { Dealing with subordinates } \\
\text { DM }\end{array}$ \\
\hline 29 & Booty, Justice in Financial management regarding booty & $\begin{array}{l}\text { FM } \\
\text { Justice }\end{array}$ \\
\hline 30 & $\begin{array}{l}\text { Pray for subordinates } \\
\text { Consultation with subordinates }\end{array}$ & $\begin{array}{l}\text { Care of subordinates } \\
\mathrm{CM}\end{array}$ \\
\hline 31 & $\begin{array}{l}\text { Take care of Muslims } \\
\text { Do not put them in danger } \\
\text { Choose the best option }\end{array}$ & $\begin{array}{l}\text { Care of subordinates } \\
\text { Best planning }\end{array}$ \\
\hline 32 & $\begin{array}{l}\text { Victory is from Allah } \\
\text { The supreme power is Allah } \\
\text { Divine Help } \\
\text { Motivate subordinates } \\
\text { Participatory management } \\
\text { Analyze the situation } \\
\text { Do not to put in worldly life } \\
\text { Reminding Akhirah } \\
\text { Follow Shariah law } \\
\text { Avoid sins }\end{array}$ & $\begin{array}{l}\text { Motivation } \\
\text { PM } \\
\text { DM } \\
\text { CM } \\
\text { Controlling }\end{array}$ \\
\hline 33 & $\begin{array}{l}\text { Remind Akhirah } \\
\text { Follow prophet } \\
\text { Fear of Allah } \\
\text { Cause of Allah } \\
\end{array}$ & $\begin{array}{l}\text { Motivation } \\
\text { Controlling }\end{array}$ \\
\hline \multicolumn{3}{|c|}{ Yazid bin Abi Sufyan; Syria } \\
\hline 1 & $\begin{array}{l}\text { Appointed as the Supreme Commander } \\
\text { Ordered the whole army to follow the orders and never to ignore } \\
\text { your insight in any matter. } \\
\text { March towards Qaisariyah as soon as possible and continue its } \\
\text { siege till it is subdued. } \\
\text { Faithful to the task. } \\
\text { Hope to Almighty and Exalted Allah for success. }\end{array}$ & $\begin{array}{l}\text { Appointment (HRM) } \\
\text { Obedience } \\
\text { Steadfast } \\
\text { Detailed strategy } \\
\text { Concept of success }\end{array}$ \\
\hline \multicolumn{3}{|c|}{ Muawiyah bin Abi Sufyan; Syria } \\
\hline 1 & Discuss detailed strategy with subordinates & $\begin{array}{l}\text { DM } \\
\text { Planning } \\
\end{array}$ \\
\hline 2 & $\begin{array}{l}\text { Responsibility } \\
\text { Concept of Ummah } \\
\text { Leaders the are the custodian of the ummah } \\
\text { Consultation mgt }\end{array}$ & $\begin{array}{l}\mathrm{CM} \\
\text { Responsibility } \\
\text { Teamwork } \\
\text { Leadership Qualities }\end{array}$ \\
\hline
\end{tabular}




\begin{tabular}{|c|c|c|}
\hline \multicolumn{3}{|c|}{ Khalid bin Walid; In the battle of Yarmuk; Syria } \\
\hline 1 & $\begin{array}{l}\text { Victory from Allah } \\
\text { Fin mgt regarding booty } \\
\text { Special consideration should be given to those who rendered } \\
\text { meritorious services }\end{array}$ & $\begin{array}{l}\text { FM } \\
\text { Motivation } \\
\text { Appreciation } \\
\text { Concept of Success }\end{array}$ \\
\hline 2 & $\begin{array}{l}\text { Corrective measures } \\
\text { Accountability of elite } \\
\text { Shariah law }\end{array}$ & $\begin{array}{l}\text { Accountability } \\
\text { Controlling }\end{array}$ \\
\hline \multicolumn{3}{|c|}{ Sa'd bin AAbi Waqqas; Forces in Iraq } \\
\hline $\mathbf{1}$ & Fin mgt regarding booty & FM \\
\hline 2 & Give strategy to avoid the risk & RM \\
\hline 3 & $\begin{array}{l}\text { Give a detailed strategy } \\
\text { Consult others } \\
\text { Be informed about the planning of your competitors }\end{array}$ & $\begin{array}{l}\text { Planning } \\
\text { CM } \\
\text { RM }\end{array}$ \\
\hline 4 & $\begin{array}{l}\text { Gve a detailed strategy } \\
\text { Be informed about the planning of your competitors } \\
\text { Decision making according to enemy planning to avoid Risk } \\
\text { Help of Allah } \\
\text { Be steadfast and firm } \\
\text { Materialistic strength does not matter } \\
\text { Do work for the pleasure of Allah } \\
\text { Victory is from Allah }\end{array}$ & $\begin{array}{l}\text { Planning } \\
\text { RM } \\
\text { DM } \\
\text { Steadfast } \\
\text { Motivation }\end{array}$ \\
\hline 5 & $\begin{array}{l}\text { Decisions according to situation } \\
\text { Situational analysis } \\
\text { Devine help } \\
\text { Take care of subordinates }\end{array}$ & $\begin{array}{l}\text { DM } \\
\text { Care of subordinates }\end{array}$ \\
\hline 6 & Situational Analysis & DM \\
\hline 7 & $\begin{array}{l}\text { Situational Analysis } \\
\text { Do not your subordinates put in danger } \\
\text { Accept the agreement on some conditions }\end{array}$ & $\begin{array}{l}\text { DM } \\
\text { RM } \\
\text { Care of subordinates }\end{array}$ \\
\hline 8 & $\begin{array}{l}\text { No fear of a large number of enemies } \\
\text { Invoke the help of Allah } \\
\text { Continuously connect with subordinates }\end{array}$ & $\begin{array}{l}\text { Motivation } \\
\text { Encourage } \\
\text { Teamwork }\end{array}$ \\
\hline 9 & $\begin{array}{l}\text { Trust in Allah } \\
\text { Do not trust in a large number of Army } \\
\text { Victory from Allah } \\
\text { Determination in difficult times } \\
\text { Risk mgt } \\
\text { Consult with seniors }\end{array}$ & $\begin{array}{l}\mathrm{RM} \\
\mathrm{CM} \\
\text { Motivation } \\
\text { Determination }\end{array}$ \\
\hline $\mathbf{1 0}$ & $\begin{array}{l}\text { Do seek advice in military matters concerning warfare from } \\
\text { Tulaiha bin Khuwalid and Umar bin Ma,di Karb because every } \\
\text { craftsman knows his job }\end{array}$ & $\begin{array}{l}\text { CM } \\
\text { The right person for the right job } \\
\text { HRM }\end{array}$ \\
\hline 11 & $\begin{array}{l}\text { Development of subordinates according to Islam } \\
\text { Guidance from the Quran }\end{array}$ & Development \\
\hline 12 & Financial management about booty & Financial management \\
\hline 13 & $\begin{array}{l}\text { Fear of Allah } \\
\text { Fulfill promise with the enemy } \\
\text { Do not Commit treachery } \\
\text { Infidelity decrease your power } \\
\text { Do not put Muslims in danger }\end{array}$ & $\begin{array}{l}\text { Development } \\
\text { Controlling } \\
\text { Corrective measures }\end{array}$ \\
\hline
\end{tabular}


International Conference on Recents Advancements in Engineering and Technology (ICRAET-18) |15th and 16th March 2019|Siddhartha Institute of Technology \& Sciences, Telangana, India.

\begin{tabular}{|c|c|c|}
\hline 14 & $\begin{array}{l}\text { Fear of Allah } \\
\text { Fulfill promise with the enemy } \\
\text { Do not Commit treachery } \\
\text { Infidelity decrease your power } \\
\text { Do not put Muslims in danger } \\
\text { Fulfil your responsibility } \\
\text { The secret of the success to avoid sins } \\
\text { Give a detailed strategy }\end{array}$ & $\begin{array}{l}\text { Development } \\
\text { CM } \\
\text { Responsibility } \\
\text { Care of subordinates } \\
\text { RM } \\
\text { Concept of success } \\
\text { Planning }\end{array}$ \\
\hline 15 & Fin mgt regarding booty & FM \\
\hline 16 & Check the efficiency of subordinates & Accountability \\
\hline 17 & $\begin{array}{l}\text { Do not insult subordinates } \\
\text { Motivate through appreciation of subordinates }\end{array}$ & $\begin{array}{l}\text { Care of subordinates } \\
\text { RM } \\
\text { Motivation }\end{array}$ \\
\hline 18 & $\begin{array}{l}\text { Accountability } \\
\text { Detailed inquiry about the issue }\end{array}$ & $\begin{array}{l}\text { Accountability } \\
\text { DM }\end{array}$ \\
\hline 19 & Give strategy to avoid risks & $\begin{array}{l}\text { RM } \\
\text { Motivation }\end{array}$ \\
\hline 20 & Compliments to your subordinates & $\begin{array}{l}\text { Care of subordinates } \\
\text { Motivation }\end{array}$ \\
\hline 21 & $\begin{array}{l}\text { Financial } \mathrm{mgt} \text { regarding booty } \\
\text { Reprimand subordinates on unusual demands } \\
\text { Accountability links to Akhirah }\end{array}$ & $\begin{array}{l}\text { FM } \\
\text { Controlling } \\
\text { Accountability }\end{array}$ \\
\hline 22 & Financial mgt regarding booty & FM \\
\hline 23 & Kufr (Disobedience to Allah) is responsible for all injustices & Reason for injustice \\
\hline 24 & $\begin{array}{l}\text { Plans for the next generations } \\
\text { Fin mgt regarding booty } \\
\text { Avoid risk which leads to quarrel }\end{array}$ & $\begin{array}{l}\text { Planning } \\
\text { RM } \\
\text { FM }\end{array}$ \\
\hline 25 & $\begin{array}{l}\text { Give protection to those who did not render help to the enemies } \\
\text { against you. }\end{array}$ & RM \\
\hline 26 & $\begin{array}{l}\text { Mentioning Allah } \\
\text { Sayings of prophet } \\
\text { Imp of Akhirah } \\
\text { Referring to the Quran } \\
\text { Follow past Muslim sahabah }\end{array}$ & Development \\
\hline 27 & Help each other in work & Teamwork \\
\hline 28 & Give strategy of teamwork & $\begin{array}{l}\text { Teamwork } \\
\text { Planning }\end{array}$ \\
\hline 29 & $\begin{array}{l}\text { Planning after victory } \\
\text { Plan for next task before completion of the task }\end{array}$ & $\begin{array}{l}\text { Planning } \\
\text { Engage subordinates }\end{array}$ \\
\hline 30 & $\begin{array}{l}\text { Strategy according to situation } \\
\text { Plan to avoid Future risks }\end{array}$ & $\begin{array}{l}\text { DM } \\
\text { Planning } \\
\text { RM }\end{array}$ \\
\hline 31 & $\begin{array}{l}\text { Give strategy of teamwork } \\
\text { Appointments according to need and situation }\end{array}$ & $\begin{array}{l}\text { Planning } \\
\text { HRM }\end{array}$ \\
\hline 32 & $\begin{array}{l}\text { Command of Amr bin Maalik at Hait, the herald of the army be } \\
\text { under the command of Harith bin Zaid Aamri } \\
\text { Right and left of the force under the command of Ribaie bin } \\
\text { Aamir and Maalik bin Habib respectively. }\end{array}$ & $\begin{array}{l}\text { Planning } \\
\text { HRM }\end{array}$ \\
\hline 33 & $\begin{array}{l}\text { Punishment for those who fight against you for a lesson for others } \\
\text { Financial mgt: same salary for the same professions }\end{array}$ & $\begin{array}{l}\text { Controlling } \\
\text { FM }\end{array}$ \\
\hline 34 & Decisions for Non-professionals according to shariah & $\begin{array}{l}\text { Appointment } \\
\text { DM }\end{array}$ \\
\hline 36 & $\begin{array}{l}\text { Take care of subordinates } \\
\text { Be linked with condition of subordinates }\end{array}$ & $\begin{array}{l}\text { Care of subordinates } \\
\text { Teamwork }\end{array}$ \\
\hline
\end{tabular}




\begin{tabular}{|l|l|l|}
\hline $\mathbf{3 7}$ & Take care of official finances & $\begin{array}{l}\text { RM } \\
\text { FM }\end{array}$ \\
\hline $\mathbf{3 8}$ & Do best and care of subordinates & Care of subordinates \\
\hline $\mathbf{3 9}$ & $\begin{array}{l}\text { A simple life for leadership } \\
\text { No hinderance between yourselves and the public. } \\
\text { Accountability of elites }\end{array}$ & $\begin{array}{l}\text { Leadership qualities } \\
\text { Accountability }\end{array}$ \\
\hline $\mathbf{4 0}$ & Teamwork strategy based on Ta'awun al birr & Teamwork \\
\hline $\mathbf{4 1}$ & $\begin{array}{l}\text { Teamwork strategy based on Ta'awun al birr. } \\
\text { Detailed strategy for future tasks. }\end{array}$ & $\begin{array}{l}\text { Teamwork } \\
\text { RM } \\
\text { Planning }\end{array}$ \\
\hline \multicolumn{2}{|l|}{ Total Letters } & $\mathbf{7 9}$ \\
\hline
\end{tabular}

\section{District Officer}

Caliph wrote a letter to the Collector Incharge of Faris Municipality of Greece about the accountability and controlling in his territory are the main quality of 'Umar's management which is in the limits of Islamic law such as his order for the execution of magicians.

\section{E. Dhimmi immigrants of Najran}

Dealing with non-Muslim is an exceptional managerial trait of Caliph 'Umar which shows his high sense of administrative responsibility such as issue of the Christians of Najran (region of SA near Yemen) which were extern according to the instructions of Prophet Muhammad, he gives full protection to them and instructs Muslims not to harm them and assigns their rights. Muslims are also advised to help them, fulfil covenant and Justice with them. He also voided Jizya (tax on non-Muslims under protection) for 24 months and realized only revenue on production as Table 5 shows.

\begin{tabular}{|l|l|l|}
\hline $\begin{array}{l}\text { Lett } \\
\text { er }\end{array}$ & Details & Theme \\
\hline $\mathbf{1}$ & $\begin{array}{l}\text { Avoid jizya \& realize revenue } \\
\text { fulfil covenant with non- } \\
\text { muslims }\end{array}$ & $\begin{array}{l}\text { FM } \\
\text { Fulfil } \\
\text { covenant }\end{array}$ \\
\hline $\mathbf{2}$ & $\begin{array}{l}\text { Avoid jizya \& realize revenue } \\
\text { fulfil covenant with non- } \\
\text { muslims }\end{array}$ & $\begin{array}{l}\text { FM } \\
\text { Fulfil } \\
\text { covenant }\end{array}$ \\
\hline Total letters & $\mathbf{2}$ \\
\hline
\end{tabular}

\section{F. Police officers}

Accountability and Corrective measures were the main components of controlling, and Caliph 'Umar has a great sense of this quality. He strictly takes corrective measures against his officers to manage system smoothly and in favor of public as he Harjaa bin Huzafa at Egypt; built a room over the roof of his house and dismantled it due to peep into neighbors.

\section{G. Public Address}

Caliph 'Umar addressed directly masses of states such as public of Syria, ru'ash (valley of Najran) and Basra in which he advises public for harmony among them using the concept of Ummah and convinced them to be obedient to their leaders.

Table 7 shows that he has a great sense of governance along with the sense of responsibility and accountability, such as he not only himself but ordered his subordinates to help grieved persons either Muslim or non-Muslim. He also instructed his officers to keep government roads safe for public convenience. While appointing or dismissal of someone, he informed and justified his decision.

\begin{tabular}{|l|l|l|}
\hline $\begin{array}{l}\text { Lett } \\
\text { er }\end{array}$ & Details & Theme \\
\hline Muslims in Syria \\
\hline $\mathbf{1}$ & $\begin{array}{l}\text { Inform them about the } \\
\text { appointment of Abu 'Obaidah. } \\
\text { Instruct to obey him. } \\
\text { Dismissal of Khalid. }\end{array}$ & $\begin{array}{l}\text { HRM } \\
\text { Obedience } \\
\text { Dismissal }\end{array}$ \\
\hline $\mathbf{2}$ & $\begin{array}{l}\text { Corrective measures for } \\
\text { Muslims who curse wrongdoers } \\
\text { Muslims. } \\
\text { Should keep eyes on your } \\
\text { doings. }\end{array}$ & CM \\
\hline Muslims of Cantonment; Syria \\
\hline $\mathbf{1}$ & $\begin{array}{l}\text { Justification for dismissal of } \\
\text { Khalid. } \\
\text { Allah is real resolver, not } \\
\text { Khalid. }\end{array}$ & CM \\
\hline Public; Ru'ash (valley of Najran) \\
\hline $\mathbf{1}$ & $\begin{array}{l}\text { Impose half of the revenue on } \\
\text { production. }\end{array}$ & FM \\
\hline People of Basra & $\begin{array}{l}\text { Inform about the appointment of } \\
\text { Abu Musa. } \\
\text { Inform about his responsibilities } \\
\text { (Job Discerption). } \\
\text { Help grieved a person. } \\
\text { Help dhimmis. } \\
\text { Realize revenue. } \\
\text { Keep government roads safe. }\end{array}$ & $\begin{array}{l}\text { Fealing } \\
\text { non-Muslims }\end{array}$ \\
\hline Total letters & $\mathbf{6}$ \\
\hline
\end{tabular}

\section{H. The Treaty of Elia}

Caliph 'Umar made a treaty with non-Muslims of Jerusalem which sheds light on the art of his managing in dealing with them. In one of his letters, he gave full freedom of religion and safety to their religious places. He also instructs Muslims to fulfil and follow covenant, which is witnessed by Allah, prophet, leaders \& Muslims. He allows them to go to their rural areas $\&$ revenue will not be charged until harvesting. Justice in imposing revenue.

\section{Emperors}

Being a Muslim leader, he also dealt with international leaders to manage international affairs. Table 9 mentions that he wrote seven letters to Byzantine emperors such as 
International Conference on Recents Advancements in Engineering and Technology (ICRAET-18) |15th and 16th March 2019|Siddhartha Institute of Technology \& Sciences, Telangana, India.

Heraclius which showed his interest in international affairs (IR). These letters consisted of Dawah towards Islam, some advice and political warning to fulfil covenant in case of release captive.

\begin{tabular}{|c|c|c|}
\hline Letter & Details & Theme \\
\hline \multicolumn{3}{|c|}{ Heraclius; Byzantine } \\
\hline 1 & $\begin{array}{l}\text { Release captive (Abdullah bin Huzafah). } \\
\text { Threat him to sending force. }\end{array}$ & Political warning \\
\hline 2 & Answer about date tree \& give Dawah. Maryam \& 'Esa & $\begin{array}{l}\text { IR } \\
\text { Advice }\end{array}$ \\
\hline \multicolumn{3}{|c|}{ Qaisar; Byzantine } \\
\hline 1 & $\begin{array}{l}\text { Advice upon his request. } \\
\text { Justice with subjects. } \\
\text { Good wishes for your subjects as you like for yourself. }\end{array}$ & $\begin{array}{l}\text { IR } \\
\text { Advice }\end{array}$ \\
\hline 2 & Answer the question & Advice \\
\hline 3 & $\begin{array}{l}\text { Answer the question as whatever you see with your eyes is truth \& } \\
\text { whatever you cannot experience through the eyes and based on } \\
\text { hearsay is false. }\end{array}$ & Advice \\
\hline 4 & $\begin{array}{l}\text { The answer about travelling time b/w earth \& heaven. } \\
\text { Five hundred years if the path is clear } \& \text { thorough. }\end{array}$ & Advice \\
\hline 5 & $\begin{array}{l}\text { Political warning to get back the Arab tribe. The threat to break } \\
\text { covenant with Christians of Dar al Islam. Send the army to your } \\
\text { country after exiling. }\end{array}$ & $\begin{array}{l}\text { IR } \\
\text { Political warning } \\
\text { Fulfil covenant }\end{array}$ \\
\hline \multicolumn{2}{|c|}{ Total Letters } & 7 \\
\hline
\end{tabular}

\section{J. Military Commanders}

The following 17 letters written to regional military commanders in Syria, Arabian Peninsula and Persia in which Caliph 'Umar's managerial qualities sum up as under:

Letters showed he used to consult his subordinates in every matter which tends to his Participatory style of management (PM). He used to accomplish the task with responsibility, Steadfast and believe in teamwork. Not only himself, but he also advised his subordinates to do so. He motivated them to avail the best skills and live Simple life. Besides a great leader, he used to accept the advice of subordinates and please to listen to advice and opinions of his subordinates. He used to care of subordinates and public regardless of Muslims and non-Muslims and shows kindness and justice with them. His financial management (FM) was based on the concept of Ta'wun al Ala Birr (cooperation). While appointment, he used to give instructions to obey him. Below Table 10 presents the key points of each letter under this category. Risk Management (RM) strategies also mentioned by him.

Table 10 illustrates the comprehensive view of letter details.

\begin{tabular}{|c|c|c|}
\hline Letter & Details & Theme \\
\hline \multicolumn{3}{|c|}{ Abu 'Obaidah \& M'az bin Jabal; Syria } \\
\hline 1 & $\begin{array}{l}\text { Accept the advice of subordinates. } \\
\text { Please, with the opinion of subordinates. }\end{array}$ & $\begin{array}{l}\text { PM } \\
\text { Motivation } \\
\text { Care of subordinates }\end{array}$ \\
\hline \multicolumn{3}{|c|}{ Other; Syria } \\
\hline $\mathbf{1}$ & Inform about the appointment of Yazid. & HRM \\
\hline \multicolumn{3}{|c|}{ Saeed bin 'Amir; Syria } \\
\hline 1 & $\begin{array}{l}\text { Instruction about slaves \& a free person who grants protection } \\
\text { to the enemy. } \\
\text { Provide safety to that enemy. } \\
\text { Beware of an outsider who does not close his identity. } \\
\text { Do in the interest of Muslims. }\end{array}$ & $\begin{array}{l}\text { Justice } \\
\text { Dealing with non-Muslims } \\
\text { Care of subordinates } \\
\text { RM }\end{array}$ \\
\hline \multicolumn{3}{|c|}{ 'Umair bin Sa'd Ansari; Syria } \\
\hline 1 & $\begin{array}{l}\text { Instruction about slaves to become Muk'atib. } \\
\text { Slaves should pay even through begging. }\end{array}$ & Care of subordinates \\
\hline 2 & $\begin{array}{l}\text { Instructions to send revenue. } \\
\text { Jizya, Zakat etc. }\end{array}$ & FM \\
\hline \multicolumn{3}{|c|}{ Arabian commanders } \\
\hline 1 & $\begin{array}{l}\text { Request for Aid in the form of soldiers, weapons etc. } \\
\text { Realize the critical condition of the Muslim army. }\end{array}$ & $\begin{array}{l}\text { FM } \\
\text { Teamwork }\end{array}$ \\
\hline
\end{tabular}




\begin{tabular}{|c|c|c|}
\hline 2 & $\begin{array}{l}\text { Praise a good job of a subordinate. } \\
\text { Instructions about future risks. } \\
\text { Conscious about companions. }\end{array}$ & $\begin{array}{l}\text { Motivation } \\
\text { Care of subordinates } \\
\text { RM }\end{array}$ \\
\hline 3 & $\begin{array}{l}\text { Sent for the help of Qutbah. } \\
\text { Resolve the booty issue. }\end{array}$ & $\begin{array}{l}\text { FM } \\
\text { Teamwork }\end{array}$ \\
\hline 4 & $\begin{array}{l}\text { Instructions to gather forces at a good place. } \\
\text { Order to inform him about location \& geography. }\end{array}$ & $\begin{array}{l}\text { Care of subordinates } \\
\text { Planning }\end{array}$ \\
\hline 5 & $\begin{array}{l}\text { Realize responsibility } \\
\text { Instructions to get skills of effective leadership } \\
\text { Do not commit excess on low rankers. } \\
\text { Avoid a luxurious life. } \\
\text { Do not commit such mistakes which cannot be forgiven. }\end{array}$ & $\begin{array}{l}\text { Responsibility } \\
\text { Development } \\
\text { Leadership qualities } \\
\text { RM } \\
\text { Care of subordinates }\end{array}$ \\
\hline 6 & $\begin{array}{l}\text { Realize responsibility about dhimmis. } \\
\text { Muslims should avoid excessing upon Dhimmis. } \\
\text { Fulfil covenant. }\end{array}$ & $\begin{array}{l}\text { Responsibility } \\
\text { Care of subordinates }\end{array}$ \\
\hline \multicolumn{3}{|c|}{ Harqus bin Zubair Sa'di; Not available } \\
\hline 1 & $\begin{array}{l}\text { Realize responsibility } \\
\text { Instruction about Muslims \& Dhimmis. } \\
\text { Do not get veil among you and your subordinates. } \\
\text { Be steadfast in the execution of the task. } \\
\text { Do not hasty to discharging duties which will cause a loss in } \\
\text { this world \& Akhirah. }\end{array}$ & $\begin{array}{l}\text { Responsibility } \\
\text { Care of public } \\
\text { Steadfast } \\
\text { RM }\end{array}$ \\
\hline \multicolumn{3}{|c|}{ Not available; Iraq } \\
\hline 1 & $\begin{array}{l}\text { Dealing with dhimmis (under the protection of the Islamic } \\
\text { state) and non-Dhimmis who render help against you. }\end{array}$ & $\begin{array}{l}\text { Dealing with non-Muslims } \\
\text { Care of subordinates }\end{array}$ \\
\hline \multicolumn{3}{|c|}{ Not available; Ahw'az (Persia) } \\
\hline 1 & $\begin{array}{l}\text { Instructions to intercept aid (commissariat) from Persia to } \\
\text { Nahawand. } \\
\text { Strategy to protect Muslims. } \\
\text { Strong yourself to become in a position to help defend your } \\
\text { nation and land. }\end{array}$ & $\begin{array}{l}\text { Care of subordinates } \\
\text { Motivation }\end{array}$ \\
\hline \multicolumn{3}{|c|}{ Nu'man bin Muqran; Nahawand (Iran) } \\
\hline 1 & $\begin{array}{l}\text { Motivate \& encourage for jihad. } \\
\text { Take care of mujahids. } \\
\text { Do not put them in hard situations. } \\
\text { Value of life of a Muslim } \\
\text { Battlefield strategies. }\end{array}$ & $\begin{array}{l}\text { Motivation } \\
\text { Care of subordinates } \\
\text { Planning }\end{array}$ \\
\hline 2 & $\begin{array}{l}\text { Appoint skilled persons. } \\
\text { Consultation from war veterans. }\end{array}$ & $\begin{array}{l}\text { HRM } \\
\text { Skills } \\
\text { PM }\end{array}$ \\
\hline \multicolumn{3}{|c|}{ Musanna bin Haarisa; Iran } \\
\hline 1 & $\begin{array}{l}\text { Get away from the target of the Iranian force, prepare military } \\
\text { posts on the rivers, canals and springs, beginning in the } \\
\text { contiguous areas of the two countries. The Christian tribes, } \\
\text { namely Rabee-ah, Mudhar and their allies should accompany } \\
\text { you along with their brave people. Tell the Arabs to prepare all } \\
\text { eventualities in the same manner as the Iranians do. }\end{array}$ & $\begin{array}{l}\text { Planning } \\
\text { RM } \\
\text { Dealing with non-Muslims } \\
\text { Teamwork }\end{array}$ \\
\hline \multicolumn{2}{|c|}{ Total letters } & 17 \\
\hline
\end{tabular}

\section{K. Banu Taghlab (Christian Tribe)}

Caliph 'Umar wrote a letter to Walid bin 'Uqbah about a Christian tribe of Banu taghlab, living in $\underline{\text { Upper }}$ Mesopotamia (modern-day Iraq) as in which he instructed to give relaxation about a levy on this tribe. As an administrator, he deals with them with kindness as he ordered not to force them to accept Islam.

\section{Ghazis of different Areas}

Muslim Ghazis of Syria and Persian want to pay zakat of their horses \& slaves. 'Umar accepted instead of same from Making (DM) while dealing with non-Muslims, be careful to make deeds with them and accept their conditions wisely, which does not lead to risks for you. Details of letters shown in Table 12 below. 
International Conference on Recents Advancements in Engineering and Technology (ICRAET-18) |15th and 16th March 2019|Siddhartha Institute of Technology \& Sciences, Telangana, India.

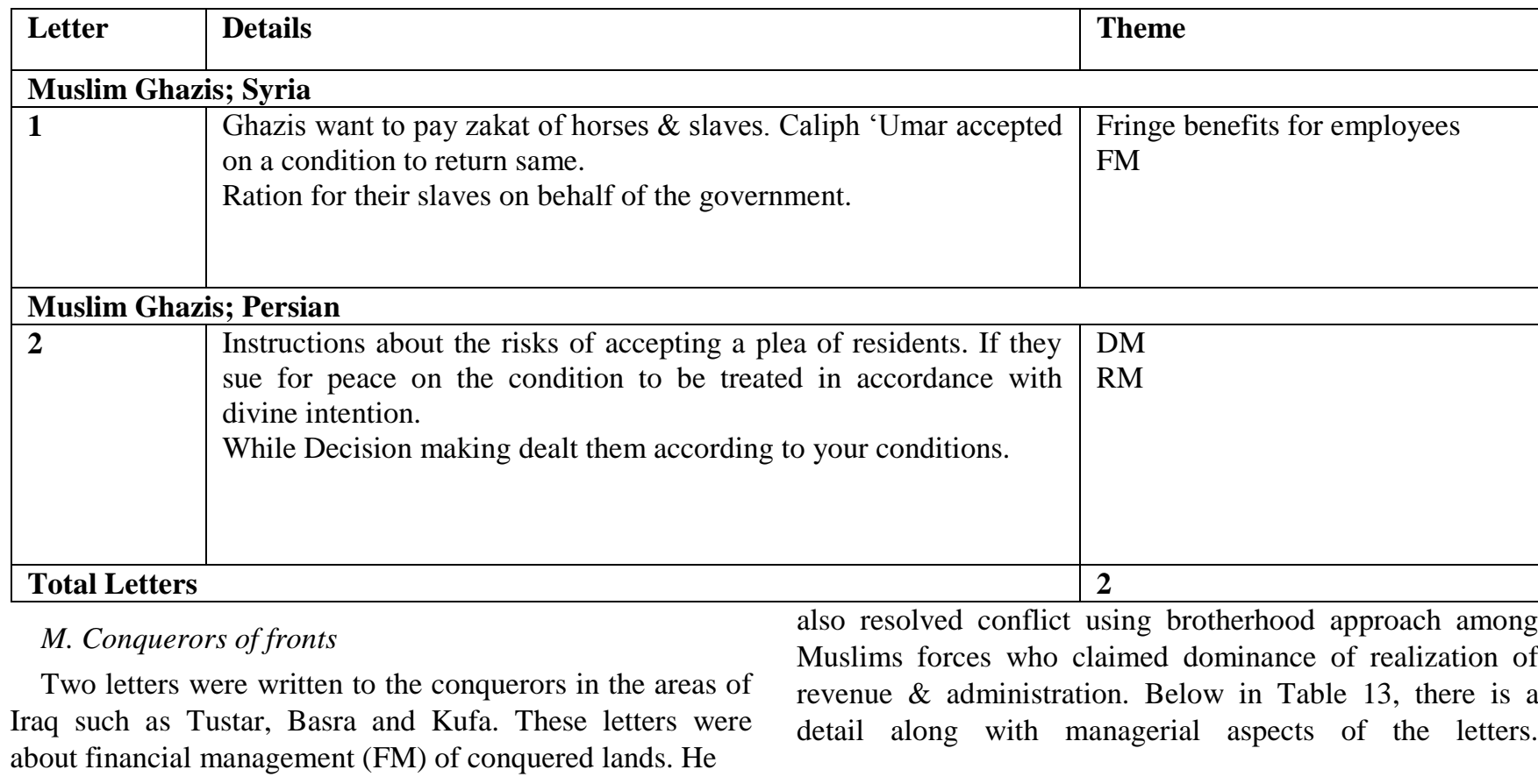

\begin{tabular}{|l|l|l|}
\hline Letter & Details & Theme \\
\hline $\mathbf{I r a q}$ & $\begin{array}{l}\text { Out of five parts of Saw'afi (land belonging to the Royal family), } \\
\text { four parts may be distributed among the conqueror army. } \\
\text { Fifth sent to the state. } \\
\text { If conqueror wishes to settle in Saw'afi, entitled them. }\end{array}$ & FM \\
\hline $\mathbf{2}$ & $\begin{array}{l}\text { Conflict among Basra \& Kufa forces on the booty. Both forces } \\
\text { claim dominance of realization of revenue \& administration. } \\
\text { Muslims are a brother. } \\
\text { Equally entitled to reap the benefit of booty. } \\
\text { Do not fight on the booty. } \\
\text { Live with peace \& considers to each other. }\end{array}$ & $\begin{array}{l}\text { Conflict resolution } \\
\text { Using brotherhood approach } \\
\text { Covelopment }\end{array}$ \\
\hline Total Letters & \multicolumn{2}{|l}{} \\
\hline
\end{tabular}

\section{N. Revenue \& Tax Collector}

Regarding financial management (FM) to manage the financial resources and revenues, he appointed Huzaifah bin Yam'an, in Tigris (Dijlah) From turkey via Iraq in Persian Gulf, 'Usman bin Haneef, in River Tigris Nu'man bin 'Adi in Maisaan (Iraq), Sa'aib bin Aqra Ma'dain (Iraq). He sent nine letters (see Table 14). Some letters were about the levy of Jizya (tax) in which he instructed those who accepted Islam before levy of jizya realize USHR. Those who accepted Islam after imposition of jizya realize only revenue. Because their land had come into our possession when they were non-muslims. Also, put a levy on different agricultural outcomes. He gave all booty among subordinates to motivation them. He believed official money does not belong to the Leader and his family. He did corrective measures of one of his financial officers and gave Justification for his decision and dismissal due to wrongdoings. He was a keen interest in the care of subordinates

\begin{tabular}{|l|l|l|}
\hline Letter & Details & \multicolumn{2}{l|}{ Theme } \\
\hline \multicolumn{1}{|c|}{ Huzaifah bin Yam'an; River Tigris (Dijlah) } & \begin{tabular}{l} 
Corrective measures \\
Controlling \\
\hline 1
\end{tabular} & $\begin{array}{l}\text { Huzaifah married Jewish women. Investigate the issue. } \\
\text { Instruction to divorce Jewish women. }\end{array}$ \\
Retrieval Number:E10820585C19/2019@BEIESP & $\begin{array}{l}\text { Published By: } \\
\text { Blue Eyes Intelligence Engineering } \\
\text { \& Sciences Publication }\end{array}$
\end{tabular}




\begin{tabular}{|c|c|c|}
\hline 2 & $\begin{array}{l}\text { Huzaifah protested. He argued from the Quran. 'Umar endorsed, } \\
\text { but he Justifies for his decision of divorce by giving an argument } \\
\text { that she will gain dominance over Arab women due to their } \\
\text { outward beauty. }\end{array}$ & $\begin{array}{l}\text { Decision making according to } \\
\text { situation }\end{array}$ \\
\hline 3 & $\begin{array}{l}\text { Those who accepted Islam before levy of jizya realize USHR. } \\
\text { Cancel the realization of Jizya on them. } \\
\text { Those who accepted Islam after imposition of jizya realize only } \\
\text { revenue because their land had come into our possession when } \\
\text { they were non-muslims. }\end{array}$ & $\begin{array}{l}\text { FM } \\
\text { DM with justification }\end{array}$ \\
\hline 4 & $\begin{array}{l}\text { Distribute all ration \& money among ghazis because he obtains } \\
\text { them. }\end{array}$ & FM \\
\hline \multicolumn{3}{|c|}{ Usman bin Haneef; River Tigris } \\
\hline 1 & $\begin{array}{l}\text { Levy on different things such as on every Jarib (160 sq. yds) } \\
\text { whether cultivated or not, one dirham in cash, one qafeez of corn, } \\
10 \text { dirhams on the cultivation of grapes, } 5 \text { dirhams on vegetables, } \\
\text { Dates \& other fruits are exempted from taxation. }\end{array}$ & $\mathrm{FM}$ \\
\hline 2 & $\begin{array}{l}\text { Order to grant land for jareer. } \\
\text { Due to his exemplary role in warfare. }\end{array}$ & $\begin{array}{l}\text { Motivation } \\
\text { Care of subordinates }\end{array}$ \\
\hline 3 & $\begin{array}{l}\text { Usman bin Haneef asked about the authenticity of the letter. 'Umar } \\
\text { endorsed. }\end{array}$ & Endorsement \\
\hline \multicolumn{3}{|c|}{ Nu'man bin 'Adi; Maisaan (Iraq) } \\
\hline 1 & $\begin{array}{l}\text { He wrote couplets for his wife to join him. Dismiss due to wrong } \\
\text { poetry in which he said about drinking wine. }\end{array}$ & $\begin{array}{l}\text { Corrective measures } \\
\text { HRM } \\
\text { Dismissal }\end{array}$ \\
\hline \multicolumn{3}{|c|}{ Sa'aib bin Aqra; Madain (Iraq) } \\
\hline 1 & $\begin{array}{l}\text { Ask Sa'aib about caught Arabs \& their slaves by rebels. Those } \\
\text { who are in custody of rebels should be handed over. } \\
\text { Slaved Arabs should be released through payment. Pay the original } \\
\text { price for the free Arabs. A free person can neither be sold nor } \\
\text { purchased. }\end{array}$ & $\begin{array}{l}\text { Care of subordinates } \\
\text { FM }\end{array}$ \\
\hline \multicolumn{2}{|c|}{ Total Letters } & 9 \\
\hline
\end{tabular}

\section{O. Qadhis (Judges)}

Caliph 'Umar's managerial potentials are also realized to educate his appointed judges. He wrote five letters to $A b u$ Qurrah and Qadi Shuraih of Kufa in which he directed about the hierarchy of Decision-making (DM) process such as while making decisions, first take guidance from Quran, the sunnah of the prophet and if you do not find clearly in
Quran \& sunnah, then refer to distinguished Mujtahids. If they fail to find a legal solution, then use your power of discretion or refer to me and it's better to refer me. This shows his preference to make decisions using participatory management (PM) style. 
He directed his judges about manners of the court, such as do not quarrel in court, do not sell or buy in court. As an administrator, he also looks after financial matters (FM) of the state in such a way instructed them to use state money properly. He continuously gets feed backs and directed them to act according to Shariah law. , The essence of above description, is available in Table 15.

\begin{tabular}{|c|c|c|}
\hline Letter & Details & Theme \\
\hline \multicolumn{3}{|c|}{ Abu Qurrah; Kufa } \\
\hline $\mathbf{1}$ & $\begin{array}{l}\text { Huzaifah married Jewish women. Investigate the issue. Instruction } \\
\text { to divorce Jewish women. }\end{array}$ & $\begin{array}{l}\text { Corrective measures } \\
\text { Controlling }\end{array}$ \\
\hline \multicolumn{3}{|c|}{ Qadhi Shuraih; Kufa (18 AH) } \\
\hline 1 & $\begin{array}{l}\text { 1st refers to Qur'an. 2nd refer to sunnah } \& \text { act accordingly. } 3^{\text {rd }} \\
\text { refer to distinguished Mujtahids. } \\
\text { Use your power of discretion or refer to me. }\end{array}$ & $\begin{array}{l}\mathrm{DM} \\
\mathrm{PM}\end{array}$ \\
\hline 2 & $\begin{array}{l}\text { Do not quarrel in court. Do not sell or buy in court. } \\
\text { Act, according to Qur'an. } \\
\text { Secondly, refer to sunnah } \\
\text { Refer to distinguished Mujtahids. Use the power of discretion \& } \\
\text { Ijtih'ad. }\end{array}$ & $\begin{array}{l}\text { DM } \\
\text { Manners of court } \\
\text { DM based on Shariah law }\end{array}$ \\
\hline 3 & $\begin{array}{l}\text { Inform about shariah ruling on Diyyah of teeth \& figure. } \\
\text { No difference in compensation for small and big teeth \& big and } \\
\text { small figure. }\end{array}$ & $\begin{array}{l}\text { DM } \\
\text { FM }\end{array}$ \\
\hline 4 & $\begin{array}{l}\text { A child brought by mother from belligerent country to Dar } \mathrm{Al} \\
\text { Islam, cannot be heir to mother. } \\
\text { Unless witnessed by the testimony of father. Mother's testimony is } \\
\text { acceptable only by tattered garments of its birth. }\end{array}$ & $\begin{array}{l}\mathrm{DM} \\
\mathrm{FM}\end{array}$ \\
\hline \multicolumn{2}{|c|}{ Total Letters } & 5 \\
\hline
\end{tabular}

\section{P. Muslim Forces}

Caliph 'Umar wrote a letter to the Muslim soldiers fighting in Jandi Saabur (city of Ahw'az) and instructed them to fulfil covenant with the inhabitants of Jandi Saabur. He justified it in such a way that faithfulness to Allah link with fulfilling the promise. He also instructed them while adoption the deed, be careful and look at every aspect of the deed.

\section{Q. Military inquiry committee}

In the conquest of Tustar (Persia), he appointed high ranked military inquiry committee to investigate an issue regarding Musa aggressive action of Jareer bin Abdullah. Through which he wanted to know the reality of an issue and decide accordingly. He also considered his officer accountable. He ordered all slave girls to release, which shows his justice.

\section{R. Dawah}

As a Khalifah, 'Umar gave priority to invite non-Muslims towards Islam. Specifically, he writes two letters for this purpose. First for Ghassani Christian Arab king, Jabalah bin Aiham, in which he motivates him that after accepting Islam you will be granted equal rights and responsibilities as Muslims. The second letter wrote to Persian forces in Nahawand front in which he directly invited them towards Islam.

\section{DISCUSSION}

After the categorization and analysis of the letters, there are 18 categories regarding audience and 33 managerial qualities and features emerged from 192 letters. Fig 2 shows that most letters are written to the Commander in chiefs which is $41 \%$ of all letters, $16 \%$ to the state governors, 
Provisional Governors are addressed in $13 \%$ of the letters while $9 \%$ of the letters are written to the military Commanders.

The second most written letters category consists of $5 \%$ Commissioner for the survey of land and assessment of revenue, Revenue collector \& Tax Collector, $4 \%$ to the Emperor of Byzantine and 3\% to the Masses of different states while $1 \%$ of the letters written to each of the following such as District officers, Dhimmi Immigrants of Najran, Police Officers, Treaty of Elia, Banu Taghlab, Ghazis, Conquerors, Judges, Muslim Forces, Military Inquiry Committee and for Dawah purpose.

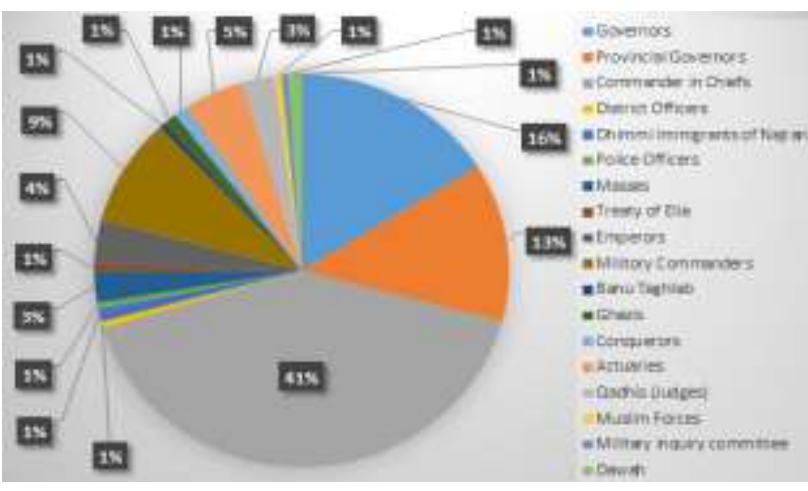

Regarding the managerial aspect, there are two categories. First consists of the core of the management, Human Resource Management (HRM), Risk Management, Financial Management and Participatory Management as Fig 3 shows. Under each category

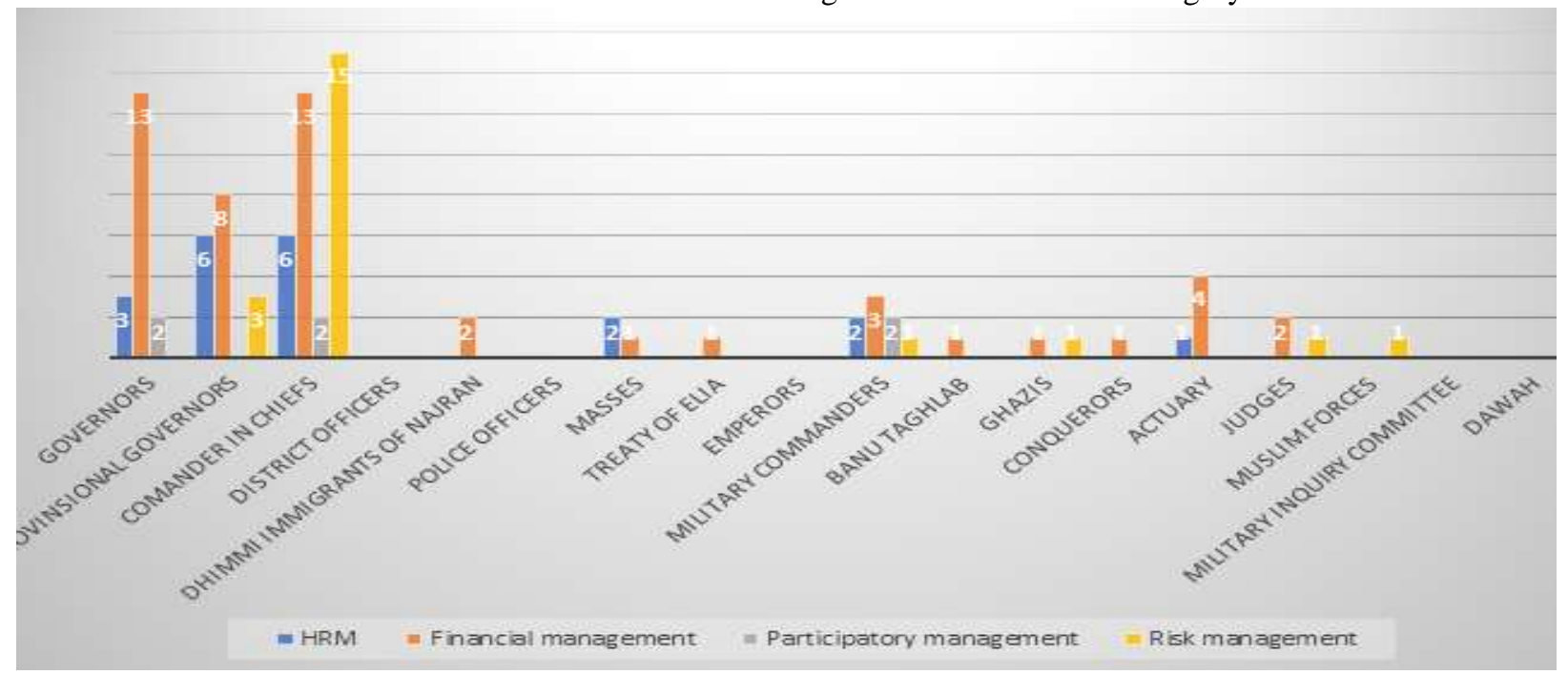

The second category relates to managerial qualities. Fig 4 employed by Caliph 'Umar to diverse people of different illustrates that there 29 administrative aspects which were

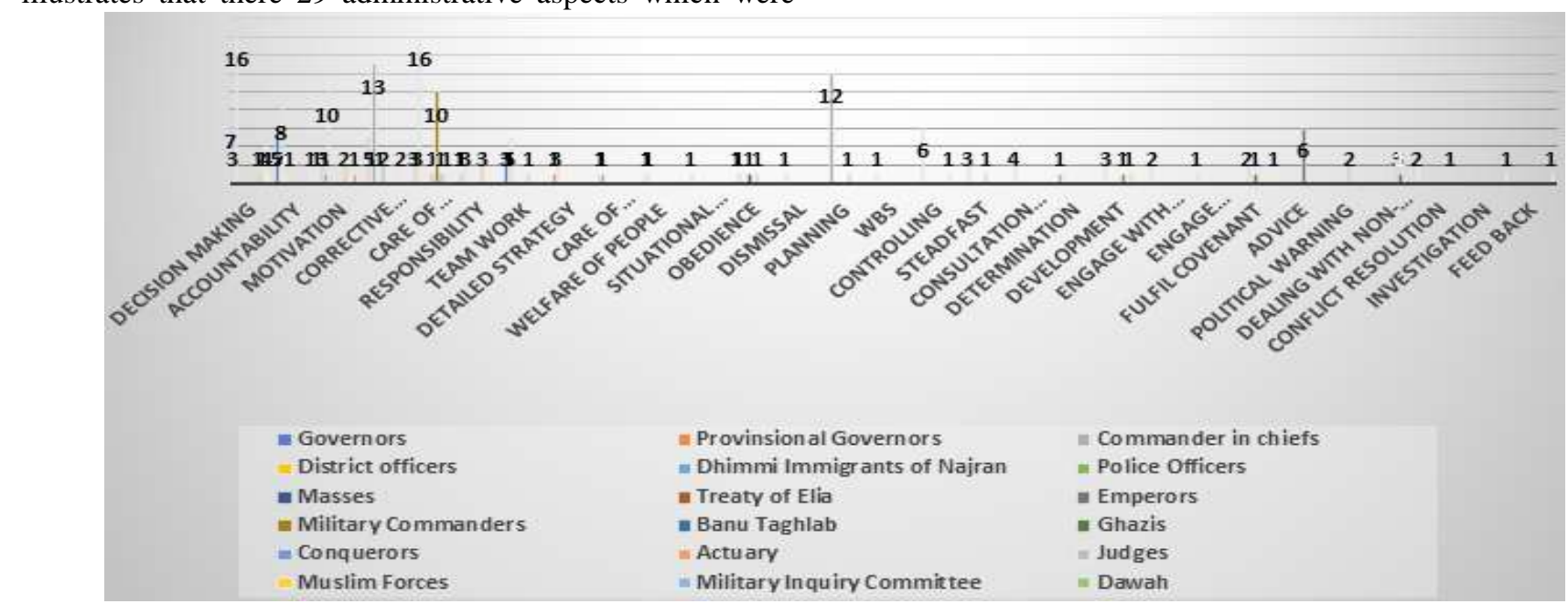
levels.

\section{CONCLUSION}

The second Caliph of Islam 'Umar ibn Al-Khattab is a unique personality regarding characteristics. His profile is blending of multifaced qualities among the great Muslims and non-Muslims leaders. Specifically, his administrative and managerial skills are unmatchable, which are shown in his letters which have been written to different tendencies of different areas. These letters show his art of management with a top-down approach on how to manage and deal with the subordinates in different situations. In this paper, we present a classification of Caliph 'Umar's letters according to the managerial qualities. 
We hope this categorization and descriptive review will deliver a portrait and reference base for leaders, managers, academics and practitioners of private and public sector organizations to develop strategies for all level of management in managing various stakeholders; at operational, tactical and strategic levels.

\section{REFERENCES}

1. Adil, M. (1991). Letters of Hadrat Umar Farooq (2nd ed.). Karachi: International Islamic Publishers Ltd.

2. Al-Nawawy, A. Z. Y. b. S. (1996). Al Minh'aj fi Sharh e Muslim bin Hajjaj. Ryadh: Bait Al Afkar al Dwalyyah.

3. Al-Tantawi, A. (1983). Akhbar e Umar. Beirut: AlMaktab al Islami.

4. Alam, S. M. (2017). Khulafa-e Rashideen: The Four Pious Khulafah. Hyderabad, India: Indian School of Excellence Trust (INDSET).

5. As-Șallābī, ‘. M. (2007). 'Umar Ibn Al-Khatțâb: His Life and Times (N. al-Khattab, Trans.). Riyadh: International Islamic Publishing House

6. Bly, R. W. (2004). Webster's New World letter writing handbook. Indianapolis: Wiley Publishing, Inc.

7. Camiciotti, G. D. L. (2014). Letters and letter writing in Early Modern culture: An introduction. Journal of Early Modern Studies, 3, 17-35.

8. F'ariq, K. A. (1978). Hadhrat Umar kay Sarkari Khutut (Ist ed.). Lahore: Idarah Islamayat.

9. Hamidullah, M. (1987). Majmu'ah al was'aiq al syasyyah li 'Ahd al Nabi wa al Khilafah al Rashidah. Beirut: Dar al Naf'ais.

10. Irving, W. (1849). Mahomet and his successors. New York and London: The Co-Operative Publication Society, Inc.

11. Nevalainen, T., \& Tanskanen, S.-K. (2007). Letter writing. Amsterdam: John Benjamins Publishing.

12. Nu'mani, S. (1939). Al-Farooq (Z. A. Khan, Trans.). Lahore: Sh. Muhammad Ashraf.

13. Petrucci, A. (2008). Scrivere lettere: una storia plurimillenaria: Laterza.

14. T'aj, R. (2007). 'Ahd e Khilafah e Rashidah main siasi khutut naweesi aur mu'ahad'at kay iblaghi pehlu ka tahqiqi aur tanqidi j'aizah. (PhD), University of Karachi, Karachi.

15. Weihrich, H., \& Koontz, H. (1995). Management: A global perspective. Singapore McGraw-Hill. 